\title{
Entrepreneurial Process: A Case of Deep Jyoti Family Resort and Restaurant Pvt. Ltd
}

\author{
Dhruba Raj Pokharel, (Ph D) \\ Associate Professor, Nepal Commerce Campus
}

\begin{abstract}
This paper carries the empirical as well as conceptual review regarding the entrepreneurial process and attempts to explore the entrepreneurial process in the tourism and hospitality enterprise creation in semi-urban area of Nepal.
\end{abstract}

\section{Background}

In the recent race of economic development countries whatever may be rich or poor, strong or weak, highly advanced or least developing are concentrating their efforts on the development activities of entrepreneurial activities. Entrepreneurship and the creation of innovative new ventures in the particular is regarded as crucial contributor to economic development (through the exploration of innovation) as well as to societal wealth (Obschonka, Silbereinsen, Rodermund, and Stuetzer, 2011). Entrepreneurship is crucial for having a healthy and rich economic structure of the country. It has been believed that the highly well-being level of the society is the outcome of entrepreneurial activities (Saiz-Alvarez, Coduras and Cuervo-Arango, 2014). In the view of Coduras and others (2016) the most dynamic countries in the world are characterized by the quality and quantity of entrepreneurship and their activities. Hence, the development level of the country, community, and the individual can easily be measured by seeing the development level of entrepreneurship.

Entrepreneurship has been regarded as the major human activity to transform the society. The importance of entrepreneurial activities has been recognized by the people all over the world. More specifically, least developed and developing economics are experiencing massive institutional transformations, which present substantial opportunities and challenges for entrepreneurial firms attempting to grow their business. Furthermore, many least developed and developing economies are moving to market based policies as a way of stimulating economic growth and reducing poverty (Boso, Story and Cadogan, 2013).

Entrepreneurship can be the human efforts to reduce poverty, social inequality, regional imbalance, and economic injustice rooted in the society. Hence, to address such societal discrepancies, promotion of the entrepreneurial activities is to be enhanced. The researchers, academicians, practicing entrepreneurs and managers should work to translate the intention of aspiring entrepreneurs into action, which is expected to bring prosperity in the individual, community and national level.

\section{Objective of the Study}


The basic objective of the case study process was to explore the stages of entrepreneurial process applied to create a venture like Deep Jyoti Family Resort and Restaurant Pvt. Ltd. To present the review of the seminal conceptual and empirical literatures related with stages in entrepreneurial process was an additional objective of the research.

\section{Research Methods}

It is the case study followed by the literature review in regard to stages in the entrepreneurial process. Available literature from the conceptual as well as empirical works of the writers and researchers have been presented in the first part of the paper. The second part of the paper presents the case of Deep Jyoti Family Resort and Restaurant Pvt. Ltd. based on the in-depth interview with its chairman and his elder son. Along with informal discussion, 20 questions were put to him in order to frame the case. Mr. Upendra Baniya, the chairman of company was friendly in the due course of interview. It was sunny morning of the 25th December, 2017, with the warm cup of coffee, and the talk with him lasted nearly in two hours. The first draft of the paper was sent to Mr. Baniya for his views on it. He reviewed it and suggested a few ideas which are incorporated in final paper. Hence, the writer assures the authenticity of the information shared here.

\section{Significance and Limitation of Study}

The study on venture creation process: A case of Deep Jyoti Family Resort and Restaurant may be valuable in the Nepalese context. This paper has attempted to review available literature concerning the stages in the entrepreneurial process. Along with literature review, the case study has presented the real Nepalese situation with the logical answer to the questions, how entrepreneurs like Mr. Baniya are launching their business with the huge amount of investment. This study also presents the transformation process of occupation, culture and value system taking place in contemporary Nepalese society. The efforts of the researchers will be fruitful, when the future researchers would be enthusiastic to study about the small and medium size enterprises scattered in different corner of Nepal, and disclosing their contribution in the process of socio economic transformation. Being a case study, there are various limitations of this study. This is the study of the unit. It is solely based on the views of single person. Therefore, the writer does not claim the generalization of the study. The company is very young, because of this; it has not experienced the ups and downs of its operation. Hence, the case is not complete, to explore the business cycle of the company.

\section{The New Venture Creation Process: Theoretical Perspective}

Enterprises are the outcome of the efforts of entrepreneurs. Over the years, the entrepreneur has been characterized as innovator creator (Schumpter, 1934), Locator, and implementer of ideas through exercises of leadership (Baumol, 1968). Others saw entrepreneurs as the actor in the process-conscious market theory who exhibit deliberate behaviors (Kirzner, 1979,1973), whereas others still view the entrepreneurs as the processor of idiosyncratic knowledge enabling opportunity recognition and finding the best ways to explore the recognized opportunities (Shane, 2003, Shane and 
Venktaraman, 2000).

The strategic planning institute (1978) has given guidelines to be a new venture. According to institution the new venture may be an independent entity, new profit center within an existing company, a joint venture satisfying the founders, investors, competitors and potential customers. The researchers in the area of new venture creation have concluded that it is not the process of single phenomena. It is deliberated collaborative process of individuals, environment, organization and the process. The following figure 1 presents collaborative way to create a new venture (Gartner, 1985). The wise entrepreneur connects the dots and creates a new venture (Baron, 2006).

\begin{tabular}{|c|c|c|}
\hline$\downarrow$ & & \\
\hline $\begin{array}{l}\text { Venture capital } \\
\text { availability } \\
\text { Presence of experienced } \\
\text { entrepreneurs } \\
\text { Technically skilled } \\
\text { labour force } \\
\text { Accessibility of suppliers } \\
\text { Accessibility of } \\
\text { customers or new } \\
\text { market } \\
\text { Governmental influence } \\
\text { Availability of land or } \\
\text { facilities } \\
\text { Accessibility of } \\
\text { transportation } \\
\text { Attitude of the area } \\
\text { population } \\
\text { Availability of support } \\
\text { services } \\
\text { Living conditions } \\
\text { High occupational and } \\
\text { industrial differentiation } \\
\text { High percentage of } \\
\text { recent immigrants } \\
\text { Large industrial base } \\
\text { Larger size of urban } \\
\text { areas } \\
\text { Availability of financial } \\
\text { resources } \\
\text { Barriers to entry } \\
\text { Rivalry among existing } \\
\text { competitors } \\
\text { Pressure from substitute } \\
\text { products } \\
\text { Bargaining power of } \\
\text { buyers and suppliers }\end{array}$ & \begin{tabular}{|l|}
\multicolumn{1}{|l|}{$\downarrow$} \\
Locates a business \\
opportunity \\
Accumulates resources \\
Markets products and \\
services \\
Products and services \\
Produces the products \\
Builds an organization \\
Responds to government \\
and society
\end{tabular} & $\begin{array}{l}\text { Overall cost leadership } \\
\text { Differentiation } \\
\text { Focus } \\
\text { The new product or } \\
\text { services } \\
\text { Parallel competition } \\
\text { Franchise entry } \\
\text { Geographical transfer } \\
\text { Supply storage } \\
\text { Taping utilized } \\
\text { resources } \\
\text { Customer contract } \\
\text { Becoming a second } \\
\text { source } \\
\text { Joint ventures } \\
\text { Licensing } \\
\text { Favored purchasing by } \\
\text { government } \\
\text { Government ruler } \\
\text { change }\end{array}$ \\
\hline
\end{tabular}

Figure: I Variables in New Venture Creation 
Carter and friends (1996) has referred the enterprise creation process by different names like gestation phase; pre-lunch activities; pre-organization; organizational emergence; organization in vetro and startup. Bygrave and Hofer (1991) explained it as the sequence of the activities, functions, or behaviors associated with the perception of opportunities, leading to the creation of new organization, a process which may take years to develop and attain objectives.

Learned (1992) conceptualized the venturing process as composed of three basic domains. According to him these processes are propensity to found, intention and sense making. As presented by Olson (1985) there are four stages in entrepreneurial process: opportunity identification; generating and examining ideas and solutions; determining choices; and implementation. Holf (1992) opined the four stages of entrepreneurial process consisting of pre start up, start up, early growth, and later growth. The researchers like Hisrich and Peters (1995) explained the four stages of enterprise creation. According to them, the stages are: identifying and evaluating the opportunity; developing the business plan; determining the resources required; and managing the resulting enterprise created. Alderich and Martinez(2001) stated that the entrepreneurial process brings together the four basic phases: conception, gestation, infancy, and adolescence.

In the view of Gibb and Ritchie (1982) the entrepreneurial process basically are consisted of five stages: finding an idea; validating the idea; identifying the resource; negotiating to get business; and birth and survival. As reviewed and presented by Baucus and Human (1994) there are five stages in the entrepreneurial process: search for business ideas; selecting the business opportunity; gathering the relevant information; formal specification; and garnering support/logistics.

As advocated by Harve and Evans (1995) the entrepreneurial process involves seven stages: conceptualize new business venture; evaluate alternative entry mode; assess financial ramifications of entering business; prospects capital; finalize company and /or product concept; form an intention to enter venture; and enter/ do not enter a new business venture. Liao and Welsch (2002)'s study reported that there are seven non-linear dynamic processes involving thirteen convergent and divergent activities: business ideas; start-up team; business plan; models/procedures; save money; lease facilities, marketing efforts, raw materials, taken courses;open account; invest money; market opportunity; and first sales. For Montanare and others (1990) there are eight sets of activities consisting of entrepreneurial pre-disposition, innovation development, environmental assessment, choice of market and start-up strategy, choice of implementation strategy, market entry, control activities, and market development. In the views of Bhave (1994) there are eleven sequential stages in the entrepreneurial process. According to him these are decision to start; opportunity recognition, opportunity refinement, business concept identified, commitment to venture creation, creation of organization, production technology and product development, sale, customer feedback, and strategic decision.

As presented above, the scholars have no integrated and deciding guidelines explaining the entrepreneurial process. It may be due to the heterogeneity of the business, geography, culture, and the value system guiding the behaviors of the entrepreneurs and the differences in the methods of study. The size and the categories of the business ventures demand distinctive stages in the entrepreneurial process. 
The present study is aimed to concentrate on a tourism based firm. Therefore the following section presents the review on tourism entrepreneurial process. In the area of tourism study Koh (1996) explained that the tourism entrepreneurial process involves eight sequential stages consisting of cognitive orientation, opportunity search, opportunity assessment, consideration, opportunity pursuit, birth, operation, and evaluation. Further Koh stated the first six stages constitute the entrepreneurial process while the last two (operation and evaluation) constitute managerial functions. In tourism field also the above sequential process would not work properly, because many tourism entrepreneurs prefer to work in individualism.

\section{Venture Creation Process: A Case Study of Deep Jyoti Family Resort and Restaurant Pvt. Ltd.}

The firm Deep Jyoti Family Resort and Restaurant Pvt. Ltd established in 2016 is situated in semi urban area of Panchkhal valley which is about $43 \mathrm{~km}$ east from Kathmandu valley and about $13 \mathrm{~km}$ far from the renown tourist destination Dhulikhel. It is on $750 \mathrm{~m}$ high from the sea level. The pollution free greenery surrounding and the adjusted temperature or climate has become the natural gift for the firm. People visiting this property find differences in the hospitality. On the top, the premises are admired for its natural beauty and kind hospitality where one can enjoy modernity in the lap of nature. Tasty foods, open space garden, joyful sheds, open and comfortable dining hall and comfortable rooms are ready to serve the visitors. The visitors can reach the property by using public as well as private means of transportation. Moreover, it is relaxing center for the people who are travelling on the long way journey. This firm represents the perfect composition of joy of rural and urban character.

Information needed to case development was collected in the sunny morning of 25th Dec. 2017 in the garden of the premises. The chairperson of the Deep Jyoti Family Resort and Restaurant and the writer conducted interactive interview or the purpose of writing the case highlighting on the entrepreneurial process. The information shared through the interview is presented on the following section.

\section{Life Sketch of the Owner}

Mr. Upendra Bahadur Baniya (61), the chair of this firm was born in the Keraghari, Bhimarkot which was their ancestral place. This family shifted to the Panchkhal valley in the year of 1966, when Nepal government controlled malaria. When his family shifted here, the valley was less populated. Only few families were residing in the basin part of the valley. The main occupation of his family was agriculture. Mr. Baniya was keen to study and obtained I. Ed from Tribhuvan University, and persuaded the teaching profession in the school located in Anaikot, nearby Panchkhal valley.

\section{Turning Point}

When the road Kodari to Kathmandu was constructed, then the farmers in the valley started to think about additional business activities. The father of Mr. Baniya was very keen to know the future and enough to think about his family. As we were talking, Mr. Baniya became so serious about the contribution of his parents to bring their child in the today's prosperity. According to Mr. Baniya his father was hardworking, simple, 
self-serving and believing on self-sufficiency. His father working hour was 15 hours a day. Due to hard work of his parents, they were able to save their earnings.

Once, when the door of possibilities were opened in the valley enterprising father of Mr. Baniya asked him to leave his profession and establish a rice, bitten rice and flour mill in the valley. He obeyed the decision of his father and started his career as the mill owner in 1983. Mr. Baniya shared happily that it was the major incident which helped to transform the family from agricultural dependency to the small level producer and traders of food stuff like rice, bitten rice, and flour. He remembers the initial investment for the mill was $\mathrm{Rs}_{\mathrm{s}}$ one lakh. This amount of fund was the saving of his parent's hard work. When the mill was transferred to his younger brother, Mr. Baniya intended into transport business by purchasing a truck container to transport goods from Khasa (Tibet) to Nepal. In the initial phase this was lucrative business for him, later it became burden not only to him but also to his family. He sold the truck container and joined hands with his father in agriculture.

As explained by Mr. Baniya, due to ill health of his mother, he needed to be in the home. The sad days prevailed in the life of Mr. Baniya. His mother passed away in 1999 and father passed away in 2003. Then after, he became the sole bread earner of the family.

\section{Establishment of Deep Jyoti Family Resort and Restaurant Pvt. Ltd}

Mr. Baniya was highly enthusiastic to share about the ideas and incidents related with this establishment. Mr. Baniya's elder son Mr. Deep Baniya, who was average in study went to Hong Kong for foreign employment. The elder son learnt the techniques and practices in the hospitality industry in Hongkong. He added that when his son returned to home, the experience brought by him became the hidden treasure to the resort. Mr. Baniya gives credit for the establishment and operation of the property to his eldest son. According to him, his son's believe on "unseen money is with tourism" is the great inspiration to him to join hands with son. He has been motivated to this firm by his son's experience and strong belief over the tourism and hospitality industry. He is proud of his both sons, because they are coordinating their works with each other, though his younger son is medical doctor and resides in Australia.

As explained by chairman, the resort occupies 21.5 ropanies of land valuing 5 lakh per ropani. The building was constructed for self-residence which has been now rejuvenated considering the need and comfort of the guests costing $\mathrm{Rs}_{\mathrm{s}} 85$ lakhs. The decoration and arrangements of necessary logistics cost Rs 50 lakhs. All the required funds for the resort was managed by the sale of land and saving of the family. The company provides employment for the six people directly. The management of the firm is under the leadership of the elder son of Mr. Baniya. Mr. Baniya is the chairperson and plays the role of patron. The company has its face to face and word of mouth promotional practices.

Mr. Baniya proudly explained its future as the real sense resort. Currently, this resort can provide accommodation for 35 guests. A well-furnished seminar hall is ready for service. A banquet hall and gym hall is under construction. As shared by him, he wants to make his resort a learning center for the students and researchers by diversifying the business as the farm house too. Tranquility is the basic theme they want to be in their resort. 


\section{Implications and Advice for future Researchers}

This case can be the motivating factor for the upcoming researchers and the writers. It has presented the conceptual and empirical findings about the stages applied and applicable to entrepreneurial process. The case of Deep Jyoti Family Resort and Restaurant is the small set up in the semi urban areas. This venture is innovative creation in this geographical location. The most admirable aspect of the company is that the promoter of the venture did not migrated in other places, but started the business in his own land from the hard earned experience. There are many more such initiatives yet to be discovered and published. Therefore, the upcoming researchers and writers are requested to promote their efforts to discover such initiatives and contribute the theory building in the sector of tourism entrepreneurship in Nepal.This study has theoretical and practical implication in Nepal. It can also be applied in the level of policy making, specifically in the field of tourism and hospitatity sector.

\section{References}

Alderich, H.E. \& Martinez, M.A. (2001). Many are called and few are chosen: A evolutionary perspective for the study of entrepreneurship. Entrepreneurship Theory and Practice, 25(4):41-56.

Baucus, D.A. \& Human S.E. ( 1994) Second career entrepreneurs: A multiple case study analysis of entrepreneurial process and antecedent variables. Entrepreneurship Theory and Practice, 19(2):41-71.

Baumol, w.j. (1968). Entrepreneurship in economic theory. American Economic Review, 58: 64-71.

Bhave, M.P. (1994). A process model of entrepreneurial venture creation. Journal of Business Venturing, 9(3):223-242.

Boso, N., Stony, V.M., \& Cadogan J. W. (2013). Entrepreneurial orientation, network ties, and performance: A study of entrepreneurial firms in a developing economy, Journal of Business venturing, 28: 708-727.

Burton, G.D., Ketchen, D.J.Jr. \& Ireland, R.D. (2013). Entrepreneurship as a solution to poverty. Journal of Business Venturing, 28: 683-689.

Bygrave, W.D. \& Hofer, C. ( 1991). Theorizing about entrepreneurship. Entrepreneurship Theory and Practice, 16(2):13-22.

Carter, N.M., Gartner, W.B., \& Reynolds, P.D. (1996). Exploring the start-up event sequence. Journal of Business Venturing, 11(3): 151-166.

Coduras, A., Saiz-Alvarez, J.M., \& Ruiz, J. (2016). Measuring readiness for entrepreneurship: An informational proposal. Journal of Innovation and knowledge, 1: 99-108.

Gartner, W.B. (1985). A conceptual framework for describing the phenomenon of new venture creation. Academy of Management Review, 10(4): 696-706.

Gibb, A. \& Ritchie, J. (1982). Understanding the process of starting small business. European Small Business Journal, 1(1):26-45.

Harvey, M. \& Evans, R. (1995). Strategic windows in the entrepreneurial process. Journal of Business Venturing, 10(5):331-347.

Hisrich, R.D. \& Peters, M.P. (1995). Entrepreneurship: Starting, Developing, and Managing a New Enterprise. Chicago,IL:Irwin.

Holt, D.H. (1992). Entrepreneurship: New venture creation. Englewood Clifs, NJ: Prentice Hall.

Koh, K. \& Hatten, T. (2002). The tourism entrepreneur: Overlooked player in tourism development studies. Journal of Hospitality and Tourism Administration, 3(1):21-48. 
Koh, K. (1996). The tourism entrepreneurial process: A conceptualization with implication for research and development. The Tourism Review, 51(4):24-41.

Koh, K. (2006). Tourism entrepreneurship: People, place, and process. Tourism Analysis, 11(2):115113.

Koh, K.Y. (2014). Mapping the tourism entrepreneurial process: A sampling from Connecticut USA. Journal of Travel and Tourism Research, Spring-Fall: 1-25.

Learned, K.E. (1992). What happened before the organization? A model of organization formation. Entrepreneurship Theory \& practice, 17(1):39-48.

Lio, J. \& Welsch, H. (2002). The temporal patterns of venture creation process: An exploratory study. Frontiers of Entrepreneurship Research, 1(1):2.

Montanari, J.R., Domicon, H.A., Oldenkamp, R.L., \& Palich, L.E. (1990). The examination of a development model for entrepreneurial firms: An empirical test. Proceeding of Academy of Management, 59-63.

Obschonka, M., Silbereisen, R.K., Rodermund, E.S.,\& Stuetzer, M. (2011). Nascent entrepreneurship and developing individual: Early entrepreneurial competence in adolescence and venture creation success during the career. Journal of Business Venturing, 79:121-133.

Olson, P.D.(1985).entrepreneurship: Process and abilities. American journal of Small Business, 10(1):25-31.

Saiz-Alvarez, J.M.,Coduras, A., \& Cuervo-Avarango, C. (2014). An entrepreneurial well-being model based on GEM for Spain. International Journal of Artificial Intelligent and Interactive Multimedia, 2(5): 38-47.

Schumpter, J.A. (1934). The theory of Economic Development. Oxford: oxford University Press.

Shane, S. (2003). General Theory of Entrepreneurship. Cheltenham: Elger.

Shane, S., \& Venkataraman, S. (2000). The promise of entrepreneurship as a field of research. Academy of Management Review, 25: 217-226.

Strategic Planning Institute. (1978).The Start-up Data Mannual. Unpublished Manuscript. Cambridge, MA: Strategic Planning Institute. 